\title{
Analisis Kinerja Reksadana Saham dan Reksadana Indeks dalam Penilaian Tingkat Efisiensi Pasar Modal di Indonesia
}

\author{
Ainani Nur Aziqoh \\ Universitas Sarjanawiyata Tamansiswa Yogyakarta, Indonesia \\ email: ainaninur22@gmail.com
}

Manuscript History:

Received: 24-02-2021

Accepted: 01-09-2021

Published: 02-09-2021

\begin{abstract}
Mutual funds are designed to raise investment funds. The objectives of this study are: to determine the performance of mutual funds on the index is higher than the performance of equity funds in the Indonesian capital market and to measure the level of efficiency in the capital market using CAPM modeling and using Net Active Value (NAV) data per Mounth for the period 2017 -2019. To determine whether a mutual fund is good or bad, it is not measured by how much the return has been generated or by how big or small the risk of fluctuation is, but this is seen from how much the mutual fund performs with its reference index. If the performance of index mutual funds is better or the performance of stock mutual funds is lower overall, the capital market can be said to be efficient. The results of this study indicate that the performance of the index mutual funds is smaller than the performance of the more superior stock mutual funds above. So it can be concluded that the Indonesian capital market is an inefficient Indonesian capital market.
\end{abstract}

Keywords: equity mutual funds; index mutual funds; capital market efficiency

\begin{abstract}
Abstrak
Reksadana dirancang untuk menghimpun dana investasi. Tujuan dari penelitian ini adalah : untuk mengetahui kinerja reksadana indeks lebih tinggi dari pada kinerja reksadana saham di pasar modal Indonesia dan untuk mengukur tingkat efisiensi pada pasar modal dengan menggunakan pemodelan CAPM dan menggunakan data Nilai Aktifa Bersih (NAB) per bulan periode 2017-2019. Untuk menentukan baik buruknya reksadana tidak diukur dari seberapa besar return yang telah dihasilkan atau dari berapa besar atau kecil risiko fluktuasi, tetapi ini dilihat dari seberapa besar kinerja dari reksadana dengan indeks acuannya. Apabila kinerja pada reksadana indeks lebih baik atau kinerja reksadana saham yang lebih rendah secara keseluruhan, maka pasar modal dapat dikatakan efisien. Hasil dari penelitian ini menunjukan bahwa kinerja reksadana indeks ternyata lebih kecil ketimbang kinerja reksadana saham yang lebih unggulan diatasnya. Maka dapat disimpulkan bahwa pasar modal Indonesia merupakan pasar modal Indonesia yang belum efisien.
\end{abstract}

Kata Kunci: reksadana saham; reksadana indeks; efisiensi pasar modal 


\section{PENDAHULUAN}

Pasar modal mampu menarik perhatian para pelaku investasi, apalagi dengan adanya perkembangan pasar modal di Indonesia, yang saat ini telah memiliki berbagai kemudahan dalam mengakses yang ditawarkan dan menjadi daya tarik kepada para investor. Selain itu reksadana juga menjadi salah satu bentuk investasi yang juga dapat memberikan kemudahan yaitu, dengan menghimpun dana dari calon investasi untuk diinvestasikan di pasar modal melalui perantara manajer investasi. Investasi merupakan bentuk pengolahan dana guna memberikan keuntungan dengan cara menempatkan dana pada alokasi yang diperkirakan akan memberikan tambahan keuntungan (compounding) (Roseliani, Akuntansi, Ekonomi, \& Telkom, 2015). Investasi ini telah menjadi suatu kebutuhan yang paling penting bagi masyarakat modern, diharapkan dengan adanya investasi ini akan dapat memberikan keuntungan dan kemudian akan dapat meningkatkan taraf hidupnya. Berdasarkan penelitian terdahulu Tona A. L (2012) yang mengatakan bahwa penilaian pada kinerja yang menggunakan raw performance dan juga risk adjusted performance dikatan bahwa kinerja reksadana indeks lebih baik dibandingkan dengan kinerja reksadana saham (secara keseluruhan) pada padasar modal Indonesia. Dan untuk penelitian terdahulu menurut Edi Pranyoto \& Susanti (2018) menyatakan bahwa secara keseluruhan untuk periode 2010-2017 pasar modal Indonesia merupakan pasar modal yang efisien, karena berdasarkan perhitungan risk adjusted performance kinerja reksadana indeks secara keseluruhan lebih baik disbanding dengan kinerja reksadana saham

Investasi strategic active management ini mengharuskan pada manajer investasi secara aktif untuk memilih dan mengubah portofolio dari waktu ke waktu sesuai dengan keadaan pasar agar keuntungan dapat menjadi maksimal. Namun juga ada kelemahan untuk strategi ini yaitu adanya banyak biaya transaksi dan juga beban oprasi yang harus ditanggung oleh reksadana itu sendiri. Reksadana berasal dari kata "reksa" yang berarti jaga atau pelihara dan untuk kata "dana" yang berarti uang. Sehingga jika seluruhnya disatukan maka reksadana dapat diartikan sebagai kumpulan uang yang dipelihara. Reksadana konvesnsional secara umum memiliki empat jenis yaitu, reksadana saham, reksadana pendapatan tetap, reksadana campuran, dan reksadana pasar uang. Pengertian reksadana secara resmi menurut UU nomor 8 tahun 1995 pasal 1 ayat 27 yang berbunyi bahwa reksadana ini merupakan wadah yang dipergunakan untuk menghimpun dana dari masyarakat atau pemodal dan untuk selanjutnya diinvestasikan dalam bentuk portofolio efek oleh manajer investasi (Yulianto \& Ispriyahadi, 2020).

Manajer menggunakan IHSG untuk dijadikan sebagai pembanding, pengelompokan reksadana dengan target yang mengalahkan benchmark disebut dengan strategi pengelolaan aktif atau disebut dengan active management strategy. Untuk baik buruknya kinerja reksadana tidak diukur dari seberapa besar return yang dihasilkan ataupun dilihat dari seberapa kecil resiko fluktuasi dari harga, tetapi ini dilihat dari hasil selisih antara kinerja reksadana dengan indeks acuannya. Namun untuk konsep pasar modal yang efisien pada kenyataannya memang sulit untuk dicapai, sehingga dari situlah dicari suatu konsep yang alternatif namun dapat 
diterima untuk pengganti konsep efisien pasar modal yang sempurna. Jadi pada pasar efisien yang sempurna, untuk pasar sekuritas akan efisien dalam hal alokasinya dan juga oprasinya. Untuk efisien dalam hal alokasi ini jika harga-harga yang ditemukan, dimana untuk marginal rate of return disemua perusahaan sama dengan marginal rate of return untuk para investornya. Pasar modal dikatakan efisien itu apabila harga dari sekuritas penuh dan secara spontan masih dapat mencerminkan segala informasi yang ada, walaupun harus mengeluarkan biaya transaksi atau biaya untuk informasi.

Kinerja reksadana pada periode terdahulu dapat dijadikan sebagai acuan dalam memilih reksadana yang memiliki prospek masa depan yang baik. kinerja reksadana dapat diukur dengan cara mempertimbangkan return dan risk rata-rata (risk-adjusted performance) dengan menggunakan reward-to-variability ratio atau Sharpe Ratio (Dana \& Dharmastuti, n.d. 2015). Dalam memilih reksadana, investor juga harus mempertimbangkan kinerja dari reksadana tersebut pada periode terdahulu. Hal ini dilakukan oleh investor dengan harapan reksadana yang dibeli akan memiliki kinerja yang baik di masa depan. Faktor lain yang diduga mempengaruhi kinerja reksadana yaitu ukuran reksadana (fund size), ukuran pada reksadana memiliki pengaruh positif terhadap kinerja reksadananya (Saputri \& Ismanto, 2020). Bahwa ukuran reksadana yang dikelola secara aktif akan memiliki pengaruh positif terhadap kinerja reksadana pula, sehingga dapat mencapai ukuran dana optimal, dimana setelah melewati ukuran dana optimal, maka ukuran reksadana akan berpengaruh negatif terhadap kinerja reksadana.

Kinerja reksadana juga berhubungan anatara tipe dari active management dengan fund size atau kinerja itu sendiri. Coronavirus Disease 2019 (COVID-19) merupakan wabah global yang telah menjalar lintas benua bahkan seluruh dunia. Wabah ini juga telah menyebabkan kurang lebih dari 8,9 milyar warga di Asia, Amerika, Eropa, Australia, Afrika, dan Antartika harus menjalani fase social distancing (menjaga jarak). Pada saat bersamaan pula IHSG ditutup 91 point $(1,67 \%)$ dan tren IHSG memang sedang bearish. Fenomena yang terjadi pada perkembangan pasar modal Indonesia saat ini sangatlah bergejolak semenjak Pandemi Covid-19. Melihat situasi perekonomian Indonesia yang sangat memprihatinkan, oleh sebab itu terdapat beberapa koreksi cukup dalam pada pasar modal. Indeks harga saham gabungan (IHSG) ini juga mengalami penurunan 22\% pada awal tahun 2020. Pasar modal yang terdapat di Indonesia menjadi salah satu Negara yang mengalami penurunan yang sangat drastis. Berdasarkan data yang ada dari infrastuktur, pertanian, aneka industry, pertambangan dan lainnya perlahan sudah mulai melemah namun sedangkan untuk sektor keuangan mengalami peningkatan. Dampak dari Pandemi Covid-19 ini menyebabkan berbagai hambatan pada aktivitas ekonomi dan perdagangan. Ditengah kondisi seperti ini Otoritas Jasa Keuangan (OJK) tidak hanya tinggal diam namun terus memantau perkembangan pasar modal di Indonesia untuk menjaga agar pasar tetap beroprasi dan bisa stabil kembali (Deasy Lestary Kusnandar1*,2020). 
Efisiensi pasar dapat diukur dari seberapa jauh harga sekuritas menyimpang dari nilai instrinsiknya. Untuk menguji efisien pasar pada kinerja suatu reksadana, maka hasil yang dicapai dari reksadana yaitu untuk pengeluaran yang tinggi dapat menghasilkan tingkat pengembaliian yang cukup tinggi pula, ini digunakan untuk mengimbangi biaya yang lebih tinggi. Maka hal ini berarti bahwa reksadana efisiensi dalam hal perdagangan dan aktivitas itu dalam penyerapan informasi. Secara keseluruhan dapat dikatakan bahwa pasar modal tidak efisien karena rata-rata reksadanna saham untuk individual ini memiliki kinerja yang lebih rendah dibanding dengan kinerja pasar (underperform), tetapi kinerja reksadana saham secara keseluruhan lebih tinggi dari pada kinerja pasar. Sedangkan peneliti ini menyatakan secara keseluruhan pasar dinyatakan efisien apabila kinerja reksadana saham lebih tinggi dari pada kinerja reksadana indeks. Tujuan dari penelitian ini adalah untuk : (1) Untuk mengetahui bagaimana kinerja reksadana indeks dan kinerja reksadana saham dalam efisien di pasar modal (2) Untuk mengetahui apakah pasar efisien dalam arti kinerja reksadana indeks lebih unggul atau sama dengan reksadana saham.

\section{TINJAUAN PUSTAKA}

\section{Pasar modal}

Pasar modal adalah pasar untuk wadah berbagai instrument keuangan yang bisa dijual belikan, antara lain seperti surat utang (obligasi), reksadana, ekuitas (saham), serta instrument lainnya. Selanjutnya untuk pengertian klasiknya yaitu dana yang didapatkan bisa digunakan untuk mengembangkan usaha, penambahan modal kerja dan lainnya (Pratama Hafidz, 2019). Pasar modal juga dapat dijadikan sebagai sarana investasi bagi masyarakat.

\section{Investasi}

Investasi merupakan suatu komitmen yang dilakukan dengan menmpatkan dana pada asset finansial maupun yang non finansial selama periode waktu tertentu. Kegiatan investasi pada umumnya dibedakan menjadi dua bentuk yaitu, dengan bentuk asset rill (real assets) maupun dalam bentuk asset finansial (financial assets) (Malik, 2017).

\section{Pasar efisien}

Pasar efisien didefinisikan sebagai pasar modal yang harga sekuritasnya mencerminkan semua informasi yang ada dan relevan. Informasi ada tiga tipe, yang pertama informasi dalam perubahan harga diwaktu lalu, kedua infomasi untuk publik (public information), ketiga informasi bentuk atau tingkatan untuk menyatakan bahwa efisiensi pasar modal (Wardani 2020).

\section{Reksadana}

Reksadana adalah wadah untuk menghimpun dana yang selanjutnya akan diinvestasikan dalam portofolio efek oleh manajer investasi (Pranyoto \& Susanti, 2018). Reksadana juga merupakan sarana investasi tepat bagi para investor yang dapat berinvestasi diberbagai instrument investasi yang telah tersedia dipasar seperti saham, 
pasar uang, obligasi,ataupun bisa juga kombinasi dari instrument tersebut. Tujuannya adalah untuk lebih mengoptimalkan keuntungan dan meminimalkan kerugian perlu juga dilakukan diverifikasi atau penyebaran dana pada beberapa instrument investasi untuk menghindari risiko kerugian secara total.

\section{Indeks Harga Saham Gabungan (IHSG)}

Menurut Damaji dan fakhruddin (2011) menyatakan bahwa IHSG merupakan indikator yang menunjukan pergerakan harga saham. Indeks ini berfungsi sebagai indicator tren pasar, yang artinya pergerakan indeks yang menggambarkan kondisi pasar pada suatu keadaan, apakah keadaan pasar sedang aktif atau sedang lesu (Astuti et al., 2016) .

\section{Return dan Risiko}

Return merupakan berupa kembalian atau bisa disebut dengan tingkat keuntungan yang dapat dinikamati oleh pemodal atas suatu investasi yang telah dilakukan. Dan untuk risikonya sendiri itu berupa tingkat potensi kerugian yang timbul karena perolehan dari suatu hasil investasi yang diharapkan namun tidak sesuai (Rusliati \& Fathoni, 2011). Return dan risiko keduanya mempunyai hubungan yaitu ketika semakin besar return yang diperoleh maka semakin besar pula resiko yang harus ditanggung.

\section{Nilai Aktiva Bersih (NAB)}

Besarnya NAB dilakukan dengan jumlah unit penyertaan (Rofiqah Wahdah Dan Joko Hartanto, 2012). Dan untuk return indeks yang lebih besar dari pada return reksadana menunjukan kinerja market yang lebih baik dari pada kinerja reksadana saham, artinya investor tidak ada yang memperoleh keuntungan yang abnormal (Pranyoto \& Susanti, 2018)

\section{SBI (Suku Bunga Sertifikat Bank Indonesia)}

Suku bungan sertifikat bank Indonesia (SBI) merupakan suku bunga dari hasil lelang sertifikat bank Indonesia (SBI) dan ini merupakan salah satu cara yang digunakan oleh otoritas moneter untuk mengendalikan jumlah uang yang beredar, nantinya akan menjaga kestabilan tingakat harga (Tiwa, Rumate, \& Tenda, 2016).

\section{METODE PENELITIAN}

Penelitian ini bersifat kuantitatif dan dilakukan dengan menggunakan metode purposive sampling, yaitu sampel yang dipilih atas dasar kesesuaian karakteristik sampel dengan ketentuan kriteria pemilihan sampel yang sudah ditentukan (Zaluchu, 2020).

\section{Populasi, Sampel, Jenis Dan Sumber Data}

Penelitian ini dilakukan pada Reksadana Saham dan Reksadana Indeks yang terdaftar dan untuk data NAB bulanan diakses melalui https://www.bareksa.com serta dari melalui Bursa Efek Indonesia atau BEI, IDX, https://www.finance.yahoo.com untuk mendapatkan data 
tahunan IHSG, situs-situs pasar modal, situs - situs reksadana, serta sumber-sumber lain yang valid. Kriteria pengambilan sampel adalah reksadana yang diteliti adalah seluruh reksadana saham dan reksadana indeks yang bersifat terbuka, reksadana saham dan reksadana indeks yang telah menerbitkan laporan bulanan mulai Januari 2017 - Desember 2019, reksadana saham dan reksadana indeks yang dana kelolaannya lebih dari 500 miliyar. Sedangkan untuk waktu yang digunakan dalam penelitian ini kurang lebih tiga tahun dari 2017 - 2019. Kriteria pengambilan sampel adalah sebagai berikut:

a. Reksadana yang diteliti adalah seluruh reksadana saham dan reksadana indeks yang bersifat terbuka.

b. Reksadana saham dan reksadana indeks yang telah menerbitkan laporan bulanan mulai Januari 2017 - Desember 2019.

c. Reksadana saham yang dana kelolaannya lebih dari 500 miliyar.

d. Seluruh reksadana indeks yang masih aktif.

e. Berdasarkan kriteria pengambilan sampel tersebut maka penelitian ini terdiri 16 reksadana saham dan 16 reksadana indeks.

Tabel 1. Penentuan Sampel Reksadana Saham

\begin{tabular}{clcl}
\hline No & \multicolumn{1}{c}{ Manajer Investasi } & Nama Produk Reksadana Saham \\
\hline 1 & PT. BPN Paribas Asset Management & - & BNP Paribas Infastruktur Plus \\
& & - BNP Paribas Pesona \\
& & - BNP Paribas Solaris \\
2 & PT. Batavia Prosperindo Aset Manajemen & - BNP Paribas Ekuitas \\
3 & PT. Danareksa Investment Management & - Danareksa Mawar Konsumer 10 \\
4 & PT. Henan Putihrai Asset Management & - HPAM Ultima Ekuitas 1 \\
5 & PT. Mandiri Manajemen Investasi & - Mandiri Investa Cerdas Bangsa \\
6 & PT. Manulife Aset Manajemen Indonesia & - Manulife Dana Saham Kelas A \\
7 & PT. Schroder Investasment Management & - Schroder Dana Prestasi Plus \\
& Indonesia & - Schroder 90 Plus Equity Fund \\
& & - Schroder Dana Prestasi \\
& & - Schroder Dana Istimewa \\
9 & PT. Sinarmas Asset Management & - Simas Saham Ungoulan \\
& PT. Syailendra Capital & - Syailendra Equity Opportunity \\
\hline
\end{tabular}

Tabel 2. Penentuan sampel reksadana indeks

\begin{tabular}{clcl}
\hline No & \multicolumn{1}{c}{ Manajer Investasi } & Nama Produk Reksadana Indeks \\
\hline 1 & PT. Bahana TCW Investment & - ABF IBI fund \\
& $\begin{array}{l}\text { Management } \\
\text { PT. Batavia Prosperindo Aset }\end{array}$ & - & Batavia LQ45 plus \\
& $\begin{array}{l}\text { Manajemen } \\
3\end{array}$ & PT. Pinnacle Persada Investama & - Pinnacle enhanced liquid ETF \\
4 & PT. Indo Premier Investment \\
& Management & - Premier EFT IDX30 \\
\hline
\end{tabular}




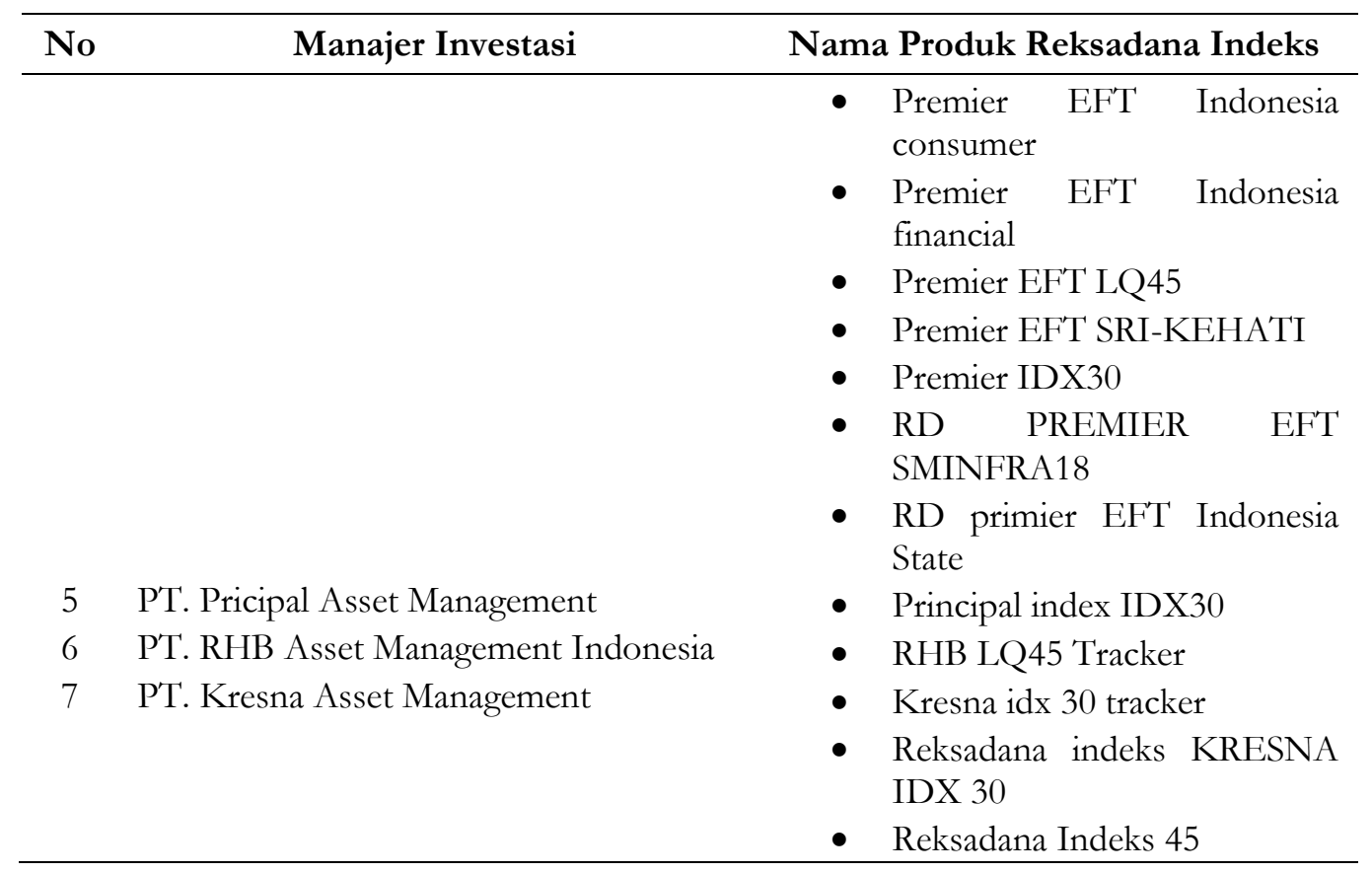

\section{Teknik Analisis Data}

a. Perhitungan return reksadana sebagai berikut:

$\mathrm{R} f d_{\mathrm{t}_{\mathrm{t}}}=\frac{N A B_{\mathrm{t}}-N A B_{\mathrm{t}-1}}{N A B_{\mathrm{t}-1}}$

dimana:

$\mathrm{Rfd}_{. \mathrm{t}}=$ return reksadana.

$\mathrm{NAB}_{\mathrm{t}}=$ nilai aktiva bersih reksadan periode $\mathrm{t}$.

$\mathrm{NAB}_{\mathrm{t}^{-1}}=$ nilai aktifa bersih reksadana periode $\mathrm{t}-1$.

b. Perhitungan return pasar sebagai berikut:

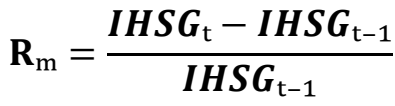

dimana:

$\mathrm{R}_{\mathrm{m}}=$ return pasar pada periode $\mathrm{t}$.

IHSGt $=$ nilai IHSG pada periode $\mathrm{t}$.

IHSGt-1 = nilai IHSG pada periode $\mathrm{t}-1$.

c. Perhitungan return asset bebas resiko

$\mathrm{R} f=\frac{S B I b}{n}$

dimana:

$\mathrm{Rf}=$ return asset bebas resiko. 
$\mathrm{SBIb}=\% \mathrm{SBI}$ bulan.

$\mathrm{n}=$ jumlah hari dalam satu bulan.

d. Perhitungan Resiko Sistematik Reksadana

$\boldsymbol{\beta}=\frac{\boldsymbol{n} \cdot \Sigma\left(\mathbf{R}_{\mathrm{m}} \cdot \mathbf{R}_{\mathrm{i}}\right)-\left(\Sigma \mathbf{R}_{\mathrm{m}} \cdot \mathbf{R}_{\mathrm{i}}\right)}{\boldsymbol{n} \cdot\left(\boldsymbol{R}_{\mathrm{m}}^{2}\right) \cdot\left(\Sigma \boldsymbol{R}_{\mathrm{m}}^{2}\right)}$

dimana:

$\beta=$ resiko sistematik reksadana

$\mathrm{n}=$ periode/jumlah

$\mathrm{R}_{\mathrm{m}}=$ return market

$\mathrm{R}_{\mathrm{i}}=$ return sekuritas ke $\mathrm{i}$

e. Perhitungan Risk Adjusted Performance (Model CAMP)

$R_{i}=R f+\beta_{i}\left(R_{m}-R f\right)$

dimana:

$\mathrm{R}_{\mathrm{i}}=$ Return reksadana indeks atau return reksadana saham.

$\mathrm{Rf}=$ Return aset bebas resiko.

$\beta_{\mathrm{i}}=$ Resiko sistematik reksadana.

$\mathrm{R}_{\mathrm{m}}=$ Return pasar.

\section{Kerangka Pikir}

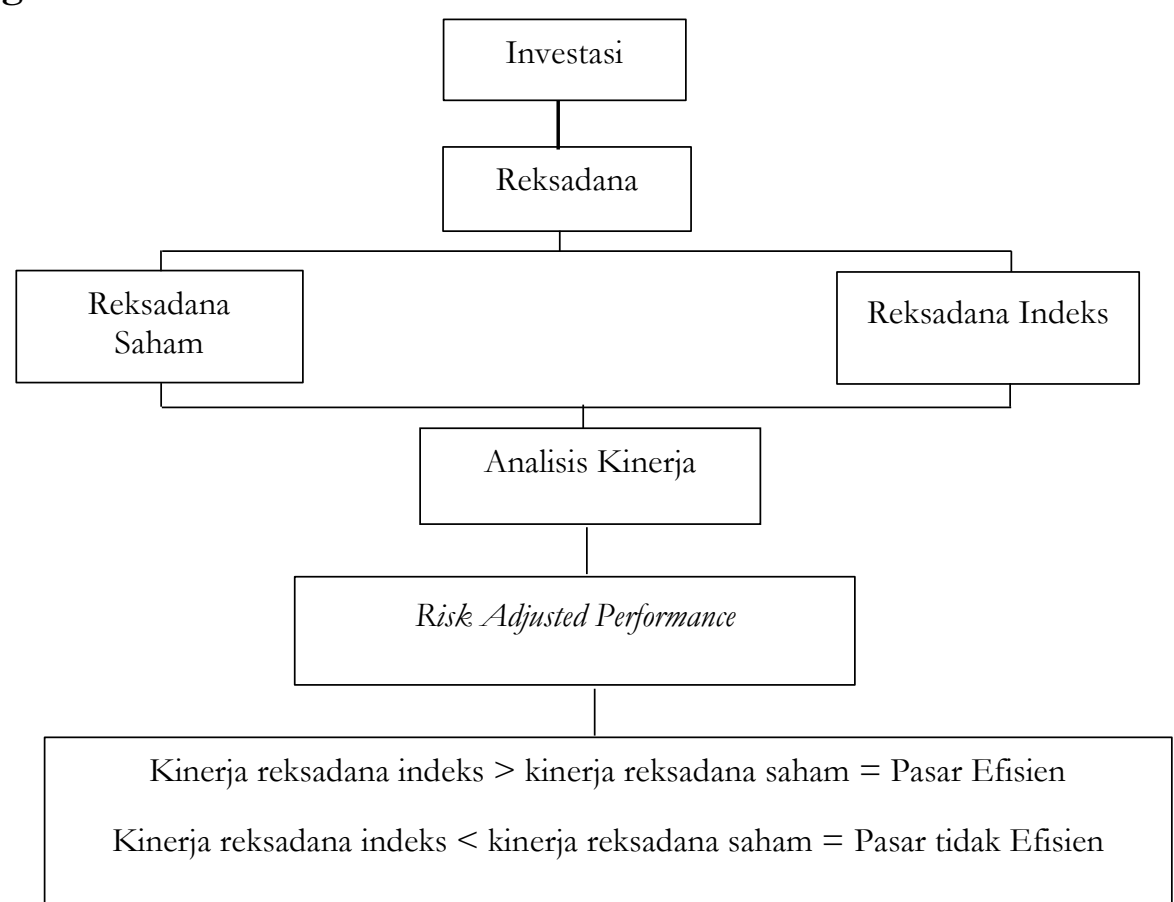

Gambar 1. Model Penelitian

(Sumber: Diolah oleh penulis, 2020) 
4. Penelitian Terdahulu

\begin{tabular}{lll}
\hline NO & \multicolumn{1}{c}{ NAMA PENELITI } & \multicolumn{1}{c}{\begin{tabular}{c}
\multicolumn{1}{c}{ JUDUL } \\
PENELITIAN
\end{tabular}} \\
\hline 1. & Nicolescu, I., & $\begin{array}{l}\text { Performance Risk analysis on } \\
\text { mutual funds versus stock } \\
\text { Tudorache, F.G., } \\
\text { exchanges in young financial } \\
\text { markets }\end{array}$
\end{tabular}

2. Chenyu Han, Yiming

Wang and Yingying Xu (2019)

Multifractality analysis: MF-DFA, market efficiency, stock market crash.

3. Himmiyatul Amanah Jiwa Juwita, Risna Wijayanti, Toto Rahardjo (2019)

Comparative Analysis of Equity Fund, Fixed Income Mutual Fund, and Mixed Mutual Fund

4. Edi Pranyoto \& Susanti

Reksadana dan Penilaian Efisiensi Pasar Modal

5. Irene Rini Demi Pangestu, Sugeng Wahyudi,Robiyanto Robiyanto (2017).

6. Yunita et al. (2016)

7. Taghi Torabi, Samaneh Tarighi, Peyman Tatnei (2016)

8. Bernadus Dwiprakasa \& Christian Fara Dharmastuti (2016)

9. Sho lihat $\mathrm{dkk}(2015)$

10. Datu Pinastiko (2014)
Performance Evaluation of Equity Mutual Funds in Indonesia.

Penerapan metode capital asset pricing model (CAPM) untuk menentukan saham-saham efisien.

Market timing, performance evaluation, mantual funds

Karatreristik reksadana dan kinerja reksadana saham di Indonesia

Analisis NAB reksadana saham, infansi, suku bunga BI, dan IHSG.

Analisis Pengukuran Kinerja Reksa Dana Saham Dengan Motode Risk Adjusted Retrun Di Bursa EfekIndonesia
Mutual funds outperform stock markets, especially during economically difficult periods. This can be take into consideration by fund administrators when deciding on their assets portfolio and when marketing their funds to investors.

Efficiency and Multifractality Analysis of the Chinese

Stock Market: Evidence from Stock Indices before

and after the 2015 Stock. Market Crash.

This study aims to find out and describe stock. mutual fund, fix income mutual fund, and mixed mutual fund. This study use a quantitative descriptive approach to describe mutual fund's performance. The study population was the all of the mutual fund with the sample of 78 mutual fund listed on Otoritas Jasa Keuangan (OJK) in accordance with predetermined criteria.

Kinerja reksadana saham dan reksadana indeks dalam penilaian tingkat efisiensi pasar modal Indonesia. The result shows that not all of the equity mutual funds studied is able to produce premium return with positive sign. It implies that the performance of those equity mutual funds is no better than the risk-free investment instruments.

Dimana 7 emiten perusahaan asuransi yang efisien dan juga 1 emiten perusahaan asuransi yang tidak efisien.

$A$ review of mutual investment funds performance with a view of market timing.

Pengaruh antara variable independen, yaitu expense ratio, fund size, turnover ratio, dan usia reksadana terhadap variable dependen. Kinerja reksadana saham Indonesia diukur dengan sharpe ratio pada tahun 2012-2013.

Tingkat suku bunga SBI dan IHSG seluruhnya yang berpengaruh secara simultan pada tingkat pengembalian reksadana saham.

Metode Sharpe Tahun 2011 Terhadap 20 Reksadana Yang Positif Dan 32 Negatif. Tahun 2012, 42 Positif Dan 10 Negatif. Tahun 2013, 6 Positif Dan46 Negatif. Metode Treynor, Tahun 2011, 20 Reksadana Positif Dan 32 Negatif. 


\begin{tabular}{|c|c|c|c|}
\hline NO & $\begin{array}{c}\text { NAMA PENELITI } \\
\text { TAHUN }\end{array}$ & $\begin{array}{c}\text { JUDUL } \\
\text { PENELITIAN }\end{array}$ & $\begin{array}{c}\text { HASIL } \\
\text { PENELITIAN }\end{array}$ \\
\hline 12. & $\begin{array}{l}\text { Ding. R. Hou. W. Kou. } \\
\text { J,M. \& Lee. E. (2013) } \\
\text { Tona Aurora Lubis } \\
(2012)\end{array}$ & $\begin{array}{l}\text { Kepemilikan Reksadana, } \\
\text { Indeks Harga Saham } \\
\text { terhadap suatu kinerja. } \\
\text { Analisis kinerja } \\
\text { reksadana saham dan } \\
\text { reksadana indeks dalam } \\
\text { penilaian tingkat efisiensi } \\
\text { pasar modal Indonesia }\end{array}$ & $\begin{array}{l}\text { Tahun 2012, } 42 \text { Reksadana Positif Dan } \\
10 \text { Negatif. Tahun 2013, } 6 \text { Positif Dan } \\
46 \text { Negatif. } \\
\text { Metode Jensen, Tahun 2011, } 19 \\
\text { Reksadana Positif Dan } 33 \text { Negatif. } \\
\text { Tahun 2012, } 12 \text { Reksadana Positif Dan } \\
40 \text { Negatif. Tahun 2013, } 19 \text { Reksadana } \\
\text { Positif Dan } 33 \text { Negatif. Metode M2, } \\
\text { Tahun } 2011 \text { Terdapat } 19 \text { Reksadana } \\
\text { Positif Dan } 33 \text { Negatif. Tahun } 2012,12 \\
\text { Positif Dan } 40 \text { Negatif. Tahun } 2013,23 \\
\text { Positif Dan } 29 \text { Negatif. } \\
\text { Pengaruh kepemilikan Reksadana yang } \\
\text { di moderasi oleh Indek harga saham } \\
\text { terhadap kinerja reksadana. } \\
\text { Dengan menggunakan penilaian } \\
\text { kinerja menggunkan raw performance } \\
\text { dan risk adjusted performance, bahwa } \\
\text { kinerja reksadana indeks LQ45 lebih } \\
\text { baik dari pada kinerja reksadana saham } \\
\text { (secara keseluruhan) di pasar modal. } \\
\text { Reksadana saham memiliki kinerja } \\
\text { lebih rendah dari pada reksadana } \\
\text { indeks LQ45 tapi ada } 2 \text { reksadana } \\
\text { saham individual yang memiliki kinerja } \\
\text { lebih baik dari pada reksadana indeks } \\
\text { LQ45. Pasar modal belum efisien pada } \\
\text { kinerja reksadana indeks LQ45 dari pda } \\
\text { reksadana saham (individual) karena } \\
\text { pasar mosal Indonesia masih berada } \\
\text { pada kelompok emerging market. }\end{array}$ \\
\hline
\end{tabular}

\section{HASIL DAN PEMBAHASAN}

Hasil analisis dilakukan pada 22 produk reksadana saham dan 1 reksadana indeks LQ-45, dengan kriteria reksadana saham yang dipilih untuk dijadikan sampel menurut dana kelolaannya lebih dari 500 miliyar dan reksadana indeks yang dipilih untuk dijadikan sampel menurut dana kelolaannya lebih dari 500 miliyar. 


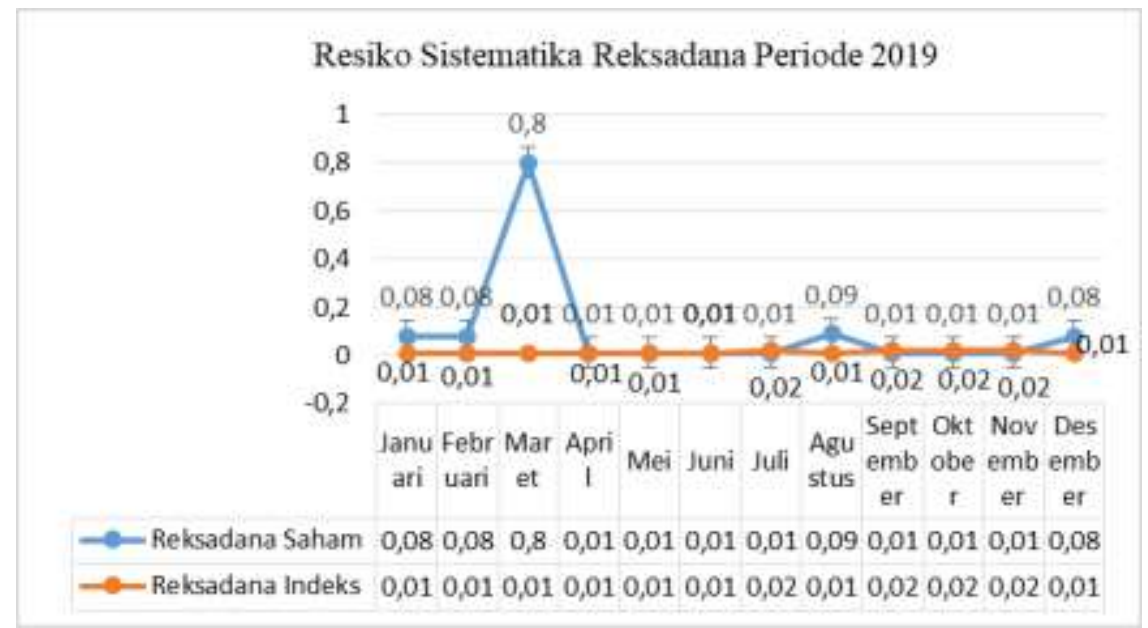

Gambar 1. Resiko sitematik reksadana

Sumber: Grafik olah data 2020

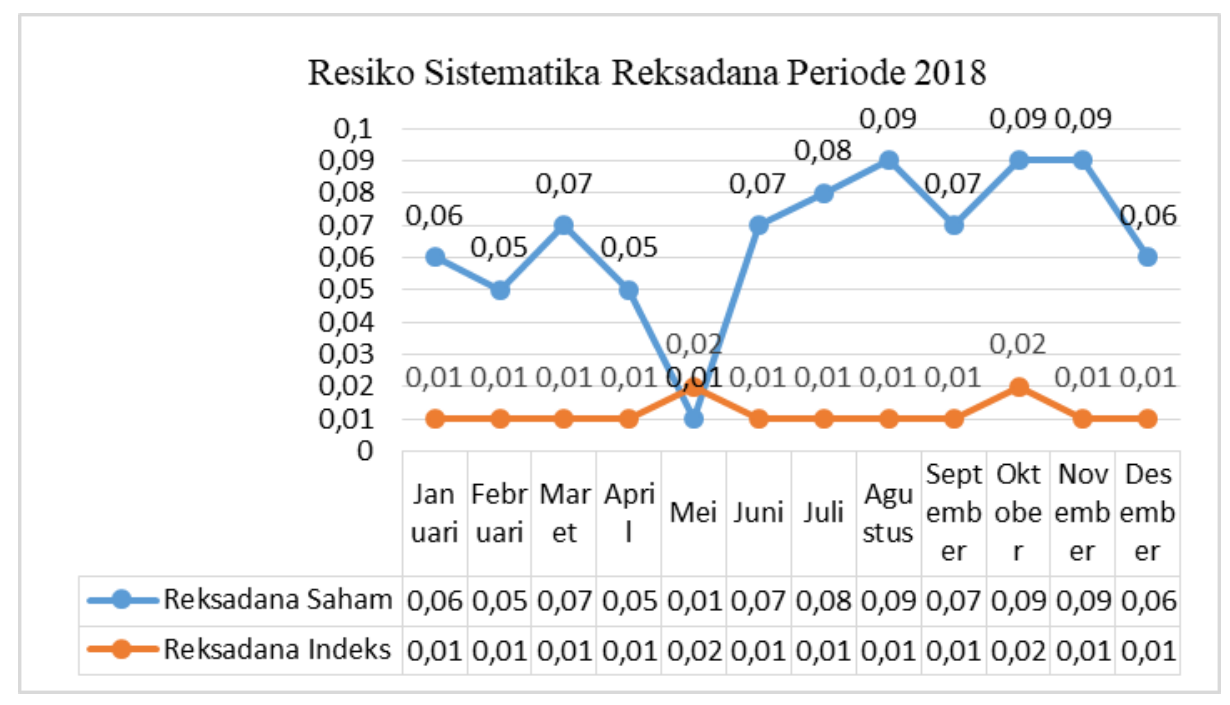

Gambar 2. Resiko sitematik reksadana

Sumber: Olah data tahun 2020

Berdasarkan grafik 1 dan grafik 2 diatas menunjukan resiko sitematik reksadana saham dan reksadana Indeks bulanan periode 2019. Menunjukan bahwa reksadanaa indeks yang memiliki nilai rendah dan reksadana saham yang memiliki nilai cukup tinggi. Sesuai dengan hasil analisis yang dilakukan oleh M. Taufiq \& M. Lorencia tahun 2020, metode apapun yang digunakan untuk mencari berbagai tingkat resiko atau pun return, akan tetap mengasilkan kinerja yang serupa (tidak ada perbedaan yang signifikan) antara kedua jenis reksadana tersebut. 


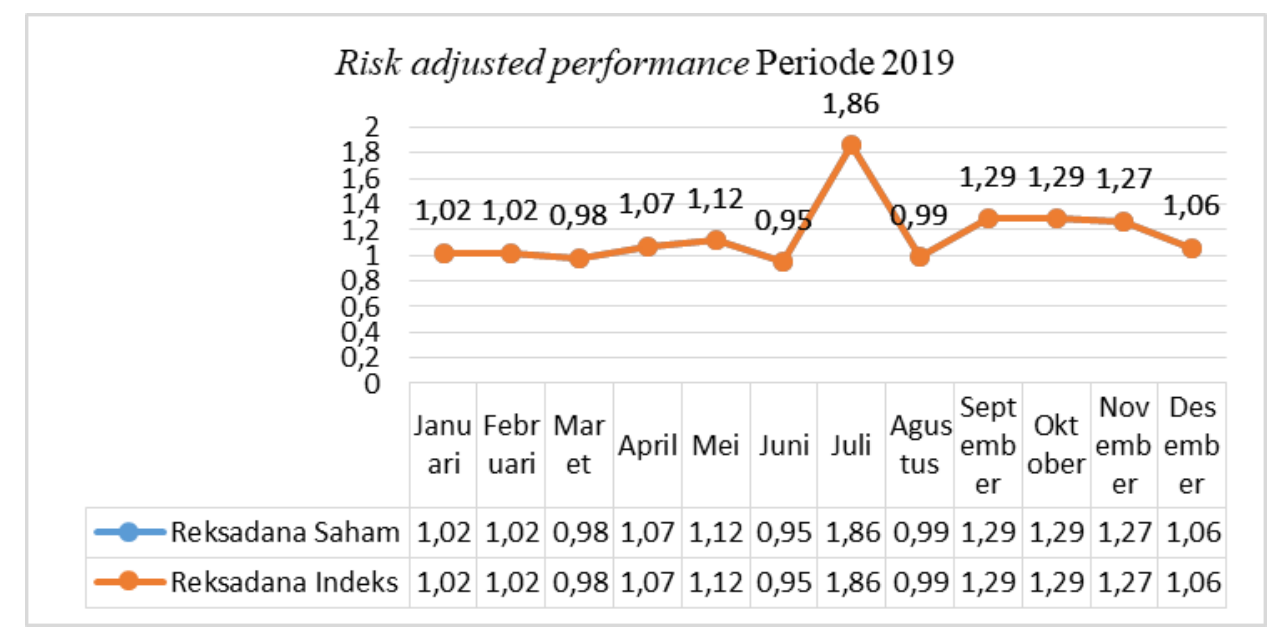

Gambar 3. Risk Adjusted Performance (model CAPM)

Sumber : Grafik olah data 2020

Berdasarkan grafik 3 diatas secara risk adjusted performance memperlihatkan bahwa risk adjusted performance pada reksadana saham dan risk adjusted performance reksdana indeks nilainya sama. Pada bulanan periode 2019. Namun hanya pada perhitungan risk adjusted performance bulanan periode 2019 ini saja yang hasilnya, selain dari bulan ditahun 2019 nilai reksadana saham masih tetap unggul, jadi untuk penelitian ini dominan reksadana saham yang lebih unggul untuk penilaian tinhgkat efisiensi pasar modal di Indonesia 2017-2019. Sesuai dengan penelitian yang dilakukan oleh Elvina Liadi et al., tahun 2020, riks adjusted performance yang diasumsikan menggunakan metode CAMP ini mampu menunjukan bahwa CAMP dapat menunjukan saham yang efisien dengan melihat apakah selisih nilai return sebenarnya dengan nilai expected return CAPM yang memiliki nilai positif/negative, nilai tinggi maupun rendah.

Kinerja reksadana dapat diukur dengan melalui beberapa metode, salah satunya dengan menggunakan risk adjusted performance. Untuk penilaiaan kinerja reksadana menggunakan alat ukur untuk kinerja secara risk adjusted performance dengan metode capital asset pricing modeling (CAPM). Apabila kinerja pada reksadana indeks lebih baik atau lebih rendah dengan kinerja reksadana saham dengan secara keseluruhan, maka pasar modal dapat dikatakan efisien.

Berdasarkan penelitian pada setiap tahun dengan alat ukur risk adjusted performance, kinerja pada reksadana saham dan reksadana indeks menunjukan kinerja yang fluktuatif. Hal ini ditunjukan diperiode bulanan 2017 sampai 2019. Pada Januari sampai Februari risk adjusted performance reksadana saham dan reksadana indeks berada diangka 1,02. Pada Maret berdasarkan risk adjusted performance reksadana saham dan reksadana indeks berada di nilai 0,98. Pada April berdasarkan pengukuran riks adjusted performance menunjukan bahwa reksadana indeks dan reksadana saham pada nilai 1,07. Pada Mei berdasarkan riks adjusted performance untuk reksadana saham dan reksadana indeks sebesar 1,12. Pada Juni berdasarkan riks adjusted performance reksdana saham dan reksadana indeks memiliki nilai 
0,95. Untuk risk adjusted performance Juli reksadana saham dan reksadana indeks sebesar 1,86. Pada Agustus berdasarkan riks adjusted performance untuk reksadana saham dan reksadana indeks sebesar 0,99. Pada September sampai Oktober berdasarkan riks adjusted performance reksdana saham dan reksadana indeks memiliki nilai 1,29. Pada November berdasarkan riks adjusted performance untuk reksadana saham dan reksadana indeks sebesar 1,27. Pada Desember berdasarkan riks adjusted performance untuk reksadana saham dan reksadana indeks sebesar 1,06. Berdasarkan hasil perhitungan tersebut maka pasar modal pada bulan Januari sampai Desember 2019 dikatakan tidak efisien, hal ini di karena adanya ketidak berhasilan majer investasi dalam mengelola produk investasi dan juga akibat pandemic covid 19 yang terjadi membuat banyak investor mangalami potensi kerugian dalam investasi tersebut dan juga adanya kinerja reksadana indeks dipengaruhi oleh sentiment negative regional yaitu anjloknya bursa china serta devaluasi yuan sehingga kinerja reksadana saham lebih unggul dari pada kinerja reksadana indeks. Pada bulan Januari 2018 juga mengalami fluktuasi pada perhitungan risk adjusted performance, reksadana saham 4,35 dan reksadana indeks berada diangka 0,84. Pada Februari berdasarkan risk adjusted performance reksadana saham 3,63 dan reksadana indeks berada di nilai 0,9. Pada Maret berdasarkan pengukuran riks adjusted performance menunjukan bahwa reksadana indeks 1,04 dan reksadana saham pada nilai 4,32. Pada April berdasarkan riks adjusted performance untuk reksadana saham 3,49 dan reksadana indeks sebesar 0,87. Pada Mei berdasarkan riks adjusted performance reksdana saham 0,68 dan reksadana indeks memiliki nilai 1,22. Untuk risk adjusted performance Juni reksadana saham 4,27 dan reksadana indeks sebesar 1,02. Pada Juli berdasarkan riks adjusted performance untuk reksadana saham 4,88 dan reksadana indeks sebesar 1,64. Pada Agustus berdasarkan riks adjusted performance reksdana saham 5,05 dan reksadana indeks memiliki nilai 1,17. Pada September berdasarkan riks adjusted performance untuk reksadana saham 4,22 dan reksadana indeks sebesar 1,21. Pada Oktober berdasarkan riks adjusted performance untuk reksadana saham 5,22 dan reksadana indeks sebesar 1,25. Pada November berdasarkan riks adjusted performance untuk reksadana saham 5,06 dan reksadana indeks sebesar 0,97. Dan untuk bulan Desember berdasarkan riks adjusted performance untuk reksadana saham 4,14 dan reksadana indeks sebesar 0,96. Berdasarkan hasil perhitungan tersebut maka pasar modal pada bulan Januari sampai Desember 2018 dikatakan tidak efisien, hal ini diduga reksadana indeks dikelola oleh manajer investasi yang lemah dalam kemampuan market timing sehingga return yang diperoleh tidak mampu menutupi risiko dan ini juga dikarenakan kenaikan suku bunga acuan namun rupiah kian melemah terhadap dollar Amerika Serikat (AS) dan pelaku pasar asing banyak yang investasi ke luar negeri, sehingga return yang diperoleh tidak dapat menutupi risiko. Pada risk adjusted performance reksadana saham dan reksdana indeks bulan Januari sampai Desember 2017 terjadi fluktuasi. Pada Januari risk adjusted performance reksadana saham 5,19 dan reksadana indeks berada diangka 1,24. Pada Februari berdasarkan risk adjusted performance reksadana saham 0,69 dan reksadana indeks berada di nilai 1,28. Pada Maret berdasarkan pengukuran riks adjusted performance menunjukan bahwa reksadana indeks 1,27 dan reksadana saham 
pada nilai 4,55. Pada April berdasarkan riks adjusted performance untuk reksadana saham 5,61 dan reksadana indeks sebesar 1,16. Pada Mei berdasarkan riks adjusted performance reksdana saham 3,45 dan reksadana indeks memiliki nilai 1,28. Untuk risk adjusted performance Juni reksadana saham 0,71 dan reksadana indeks sebesar 1,11. Pada Juli berdasarkan riks adjusted performance untuk reksadana saham 0,63 dan reksadana indeks sebesar 1,27. Pada Agustus berdasarkan riks adjusted performance reksdana saham 4,51 dan reksadana indeks memiliki nilai 1,17. Pada September berdasarkan riks adjusted performance untuk reksadana saham 3,92 dan reksadana indeks sebesar 1,22. Pada Oktober berdasarkan riks adjusted performance untuk reksadana saham 5,36 dan reksadana indeks sebesar 1,14. Pada November berdasarkan riks adjusted performance untuk reksadana saham 0,65 dan reksadana indeks sebesar 1,16. Dan untuk bulan Desember berdasarkan riks adjusted performance untuk reksadana saham 0,44 dan reksadana indeks sebesar 1,00. Berdasarkan hasil perhitungan tersebut maka pasar modal pada bulanan tahun 2017 dikatakan tidak efisien hal ini diduga karena pada kinerja reksadana indeks manajer investasi lemah dalam kemampuan stock selection dan market timing sehingga return yang diperoleh tidak mampu menutupi risiko yang ada.

Secara keseluruhan selama dari bulan Janiuari sampai Februari periode 2017-2019 pada pasar modal Indonesia belum efisien karena berdasarkan perhitungan risk adjusted performance kinerja reksadana saham secara keseluruhan lebih unggul dari pada kinerja reksadana indeks. Penelitian ini sejalan dengan yang dilakukan oleh Sumsuri (20013) yang menyatakan secara keseluruhan pasar modal Indonesia belum efisien, karena kinerja reksadana indeks berada dibawah dari kinerja reksadana saham secara keseluruhan.

\section{SIMPULAN}

Berdasarkan analisis, perhitungan dan pembahasan maka dapat disimpulkan bahwa secara keseluruhan selama periode bulanan 2017-2019 pasar modal Indonesia adalah tidak efisien, maka dapat disimpulkan sebagai berikut :

1. Dengan penilain yang menggunakan risk adjusted performance (model CAPM), analisis kinerja reksadana indeks dan kinerja reksadana saham untuk peroide tahun 2017-2019 pasar modal Indonesia dikatakan belum efisien.

2. Pasar modal Indonesia pada periode 2017-2019 dikatakan belum efisien. Karena secara keseluruhan dengan hasil perhitungan menunjukan bahwa kinerja reksadana indeks memiliki nilai yang berada di bawah kinerja reksadana saham.

\section{DAFTAR PUSTAKA}

Astuti, R., Lapian, J., Rate, P. Van, Manajemen, J., Bisnis, E., \& Ratulangi, U. S. (2016).

Pengaruh Faktor Makro Ekonomi Terhadap Indeks Harga Saham Gabungan (Ihsg) Di Bursa Efek Indonesia (Bei) Periode 2006-2015. Jurnal Berkala Ilmiah Efisiensi, 16(2), 399_ 406. 
Deasy Lestary Kusnandar1*, V. I. B. (2020). Perbandingan Abnormal Return Saham Sebelum dan Sesudah Perubahan Waktu Perdagangan Selama Pandemi Covid-19 Jpmb 195. Jurnal Pasar Modal Dan Bisnis, 2(2), Pp. 195-202, 2(2), 195-202.

Gede, L., \& Artini, S. J.Binsis (2018). Nasional dan Asing di Indonesia Dilihat dari Kinerja, Fakultas Ekonomi dan Bisnis Universitas Udayana, Bali, Indonesia Pendahuluan Reksadana merupakan salah satu alternatif berinvestasi bagi pemodal atau investor yang memiliki dana terbatas tidak mem. 3, 649-678.

Malik, A. D. (2017). Jurnal Ekonomi. MELALUI BURSA GALERI INVESTASI UISI. 3(1), 61-84.

Pranyoto, E., \& Susanti. (2018) J. Bisnis. Reksadana dan Penilaian Efisiensi Pasar. 17-25.

Pratama Hafidz, G. (2019). Efisiensi Pasar Modal Indonesia Pada Tahun Pemilu 2019. Jurnal Ekonomi, $\quad 000, \quad 169-179$. Retrieved from https://www.researchgate.net/publication/338886471

Roseliani, B.,Jurnal Akuntansi, P. S., Ekonomi, F., \& Telkom, U. (2015). Efek Anomalis Pasar Terhadap Retrun Saham ( Perusahaan LQ-45 Yang Terdaftar Di Bursa Efek.

Tiwa, F. R., Rumate, V., \& Tenda, A. (2016). Pengaruh Investasi, Suku Bunga Sertifikat Bank Indonesia (Sbi) Dan Jumlah Uang Beredar Terhadap Pertumbuhan Ekonomi Indonesia Tahun 2005-2014. Jurnal Berkala Ilmiah Efisiensi, 16(2), 344-354.

Yulianto, A., \& Ispriyahadi, H. (2020). Analisis Volatilitas Imbal Hasil Reksadana Saham (StudiKasusPada Reksadana Schroder Dana Prestasi Plus). Jurnal Ekobis : Ekonomi Bisnis \& Manajemen, 8(2), 76-90. https://doi.org/10.37932/j.e.v8i2.38 